Available Online: https://proceeding.researchsynergypress.com/index.php/cset/index

RSF Conference Series: Engineering and Technology

ISSN XXXX-XXXX (Online) | XXXX-XXXX (Print)

Volume 1 Number 1 (2021): 239-243

\title{
Application of Sheep Urine Fermentation and Biochar Coconut for Growth Vegetables Plant
}

\section{Susila Herlambang1*, Danang Yudhiantoro² ${ }^{2}$ Indriana Lestari ${ }^{3}$, Muammar Gomareuzzaman ${ }^{4}$}

\author{
${ }^{1 *}$ Department of Soil Science Faculty of Agriculture, UPN “Veteran”Yogyakarta Indonesia \\ ${ }^{2}$ Department of Management, Faculty of Business Economics, UPN “Veteran”Yogyakarta Indonesia \\ 3Department of Chemical Engineering, Faculty of Industrial Engineering, UPN “Veteran"Yogyakarta Indonesia \\ ${ }^{4}$ Department of Environmental Engineering, Faculty of Mineral Technology, UPN “Veteran”Yogyakarta Indonesia
}

\begin{abstract}
The Covid-19 pandemic to date has had an impact on all sectors of life in society, which is the provision of food sources by society. Various efforts have been made to the fulfillment of food needs in the community can fulfill as they should so that food security can be realized during this pandemic. This research was conducted so that the community can fulfill their needs, especially food needs by utilizing waste, especially solid, and liquid waste and increasing the productivity of food crops to increase the fulfillment of community needs. This research was conducted applied soil ameliorant coconut biochar at coastal soil Samas beach. After that application sheep urine fermentation for add nutrient in the soil. The stages of carrying out this research include: taking soil samples, preparing materials for making biochar and urine fermented for fertilizer, nursery pakcoy, preparing planting media, soil ameliorant coconut shell biochar, transferring pakcoy seeds, maintaining and administering urine fertilizer treatment to planting media, and plant vegetative observations. The result application was added material both biochar and sheep urine fermented. It was mixed media can repaired root area in the soil and increase avaibility of nutrient for supporting growth of stem height, account of leaves, length, width, and color of the leaf with the application of coconut shell biochar dosage 15 tons per hectare mixed treatment sheep urine $100 \mathrm{ml}$ per liter of water was best treatnment. It can good growth pakcoy plants. and Its benefit from a relatively short period, and It can reduce the use of chemical fertilizers that It can cause environmental degradation
\end{abstract}

Keywords: Biochar coconut shell, coastal soil, cultivation of growth, sheep urine fermentation and nutrient.

This is an open access article under the CC-BY-NC license

\section{INTRODUCTION}

The pandemic covid-19 has hampered all activities carried out by the community. The economic level of the people in Indonesia, especially in the Province of the Special Region of Yogyakarta. It's also affected to impact increased number of poor people by 27.42 thousand people (Anonymous, 2021). This affects the community's ability to meet their daily needs during this pandemic, especially meeting the need for food.

Horticultural crop commodities are agricultural sector commodities that are in demand in the market. The increase in market demand for horticultural products reached $11 \%$. This condition is influenced by the high public awareness of the importance of horticultural commodities not only as food ingredients, but also contributing to health, aesthetics, and environmental aspects as well as being a source of income for farmers and the community (Anonymous, 2017).

In relation to the need for horticultural commodities and the demand for organic fertilizers as well as efforts to reduce the use of chemical fertilizers, various methods and development of fertilizers obtained from natural sources is one alternative that is relatively easy, i.e. types of organic fertilizers and compost. There are two types of organic fertilizers sourced from the remains of living things, namely solid organic fertilizers and liquid organic fertilizers. One source of liquid organic fertilizer is sheep urine (Rizki et al., 2014).

\section{LITERATURE REVIEW}


Biochar was solid material rich in carbon and as a result of the conversion of waste or organic wasterich lignin through pyrolysis, incomplete combustion, or combustion with a limited oxygen for prosess burning (Nurida et al., 2015). In simple terms, biochar was produced by matterial rich lignin in solid wastes about wood, coconut shells, straw, and the other agricultural waste residues to burning with zero or less oxigen on the temperatures more than $600{ }^{\circ} \mathrm{C}$ (Herlambang et al., 2020a). Biochar stands for biologically charcoal due to the black carbon content obtained from biomass. It is processed through combustion with a limited amount of oxygen at a temperature under $700{ }^{\circ} \mathrm{C}$ to produce organic matter containing carbon of about 70 to $80 \%$ (by mass) (Lehmann and Joseph, 2012). However, it distinguishes biochar from similar types of charcoal-based on its actual application that it is synthesized to increase soil productivity, carbon storage (C), or groundwater infiltration filtration. Biochar in the form of recalcitrant carbon has many benefits ranging from waste management to soil improvement and carbon sequestration and climate change mitigation. Some studies have shown that the implementation of biochar into the soil has various advantages related to improving soil quality, including (1) stimulating nitrogen fixation symbiosis in legumes; (2) improve arbuscular mycorrhizal fungi, (3) improve soil structure; (4) increase fertilization efficiency; (5) increase cation exchange capacity (CEC); (6) increase the water holding capacity; (7) increase soil microbial biomass; (8) increase soil microbial respiration; (9) reduce by-product gases $\mathrm{CH}_{4}$ and $\mathrm{N}_{2} \mathrm{O}$ released into the air; (10) reduce soil acidity; and (11) reduce aluminum poisoning (Herlambang et al., 2020 ${ }^{\mathrm{b}}$.

Urine, both animal and human products, includes liquid waste that is easily accessible, inexpensive and is an organic product that contains high nutrients for plant growth (Sutradhar et al., 2021). Urine waste contains various substances needed for plant growth. Urinary fermentation waste contains nutrients, phosphorus, nitrogen, and potassium that plants need and can improve nutrients in the soil (Kurniawan et al., 2017). Meanwhile animal waste (both manure and urine) can routinely be applied to crop fields on large farms with good mechanism, where it is not widely used at the small holder family farm. The technical equipment was limited include of the supports further process, unpleasant smell of manure and urine, and social costums in the society was prevented treatments. The combination of manure, urine, and biochar produces an odorless, dense, and nutrient-rich organic fertilizer (Mariwah and Drangert, 2011).

Pakcoy (Brassica rapa $L$ ) was one of the vegetables crops with high economic value. Pakcoy can grow well in the highlands and lowlands (Haryanto et al., 2006). The productivity of horticultural crops, especially pakcoy, is still relatively low. This is caused by several factors, including plant cultivation techniques that are not yet intensive, rainfall and climate factors, and the influence of low soil fertility. Agricultural production, especially horticultural crops in dry areas, is also affected by high environmental temperatures, limited of water availability, low organic carbon and soil nutrients in alluvial sandy soils (Ingold et al., 2015). Efforts that can be made to increase the production of horticultural crops include the provision of fertilizers. Fertilization is carried out to meet the nutrient needs of plants so that they can provide better results (Ria and Asmuliani, 2017)

\section{RESEARCH METHODOLOGY}

This research was carry out at green house Agriculture faculty, Universitas Pembangunan Nasional Veteran Yogyakarta. The type of soil used was Coastal sandy soil and the research site was shaded with a shading net, for protection from the intensity of the sun and insects. In the initial stage, biochar is incubated for one month before being used as a soil enhancer. After the incubation period, biochar is mixed with sandy soil at a certain ratio. After planting, fermented sheep urine was applied to the growing media with a certain volume four times a week.

The stages of this research include: Soil sampling; Preparation of materials for making biochar and sheep urine; Pakcoy seed nursery; Preparation of planting media; Application coconut sheel biochar for soil ameliorant in the coastal beach, the dosage of Biochar about: a) B0 = no treatment, b) B1 $=10$ tons per hectare, c) B2 = 15 tons per hectare, d) B3 = 20 tons per hectare; Transfer of pakcoy seedlings; Maintenance and treatment of urine fertilizer to the planting media (done once a week for 4 times; Provision of urine fertilizer as much as $20 \mathrm{ml}$ per treatment), Treatment (Urine): a) U0 = no treatment, b) U1 $=50 \mathrm{ml}$ per liter of water, c) U2 $=100 \mathrm{ml}$ per liter of water, d) U3 $=150 \mathrm{ml}$ per liter of water, e) U4 $=200 \mathrm{ml}$ per liter of water; Vegetative observation of plants with observation parameters: a) Plant height; b) Number of leaves; c) Width and length of leaves; d) Leaf color. 


\section{FINDING AND DISCUSSION \\ Plant Height}

The results of testing and the application of biochar to the growing media as well as the administration of sheep urine with various treatments gave a significant effect on the average plant height of pakcoy. It is hoped that the treatment of biochar and sheep's urine will help increase the availability of nutrients that can be utilized by plants and increase the content of organic materials in the growing media which serves to improve and maintain important properties such as physical, chemical and biological. Significant results related to pakcoy plant height occurred in biochar treatment of 15 tons per hectare and sheep urine treatment of $200 \mathrm{ml}$ per liter of water, which was 9-10 cm high compared to pakcoy plants without biochar and sheep urine treatment, which was $5 \mathrm{~cm}$ high.

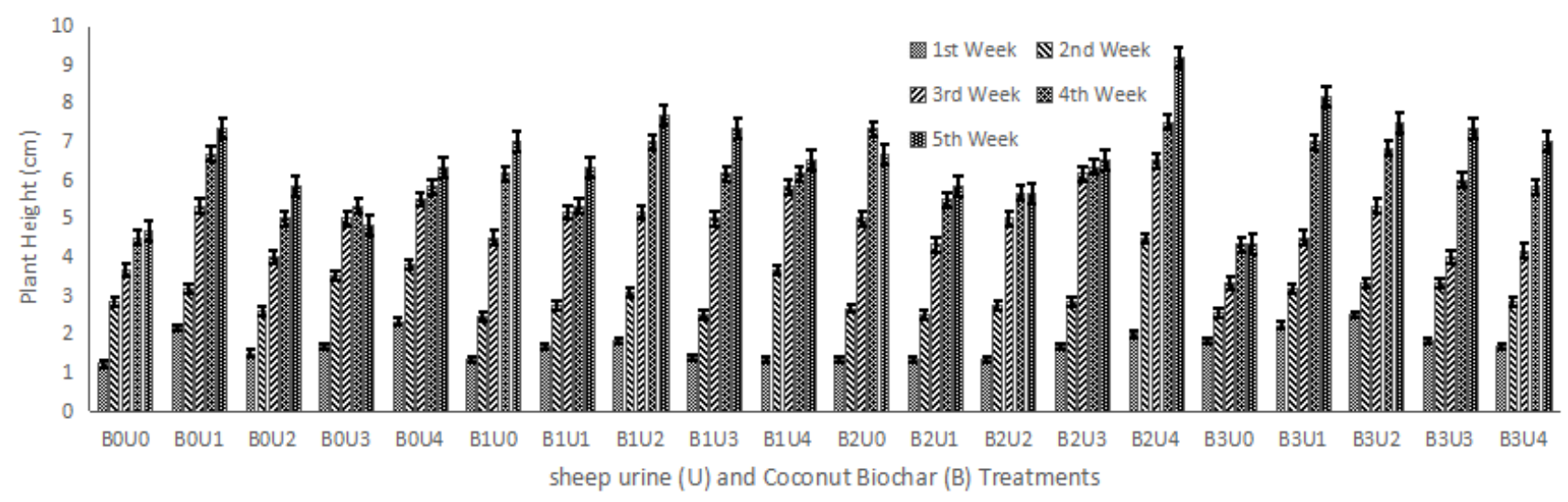

Figure 1. Aplication sheep urine fermentation and biochar coconut in the plant height at Coastal sandy soil

\section{Number of Leaves}

The increase in the number of leaves became more along with the increase in the treatment of biochar and sheep urine and also this was directly proportional to the height of the pakcoy plant. The taller the plant, the more leaf segments on the stem of the plant, and the more the number of leaves that will grow. The process of leaf growth is also inseparable from the role of nutrients obtained by plants, i.e. nitrogen and phosphate contained in the planting media which are then bound and passed on by plant roots to help growth. Significant results related to the number of leaves that occurred in the biochar treatment of 20 tons per hectare and the sheep urine treatment of $100 \mathrm{ml}$ per liter of water, which was 14 leaves compared to the pakcoy plant without biochar and sheep urine treatment, which was 11 leaves.

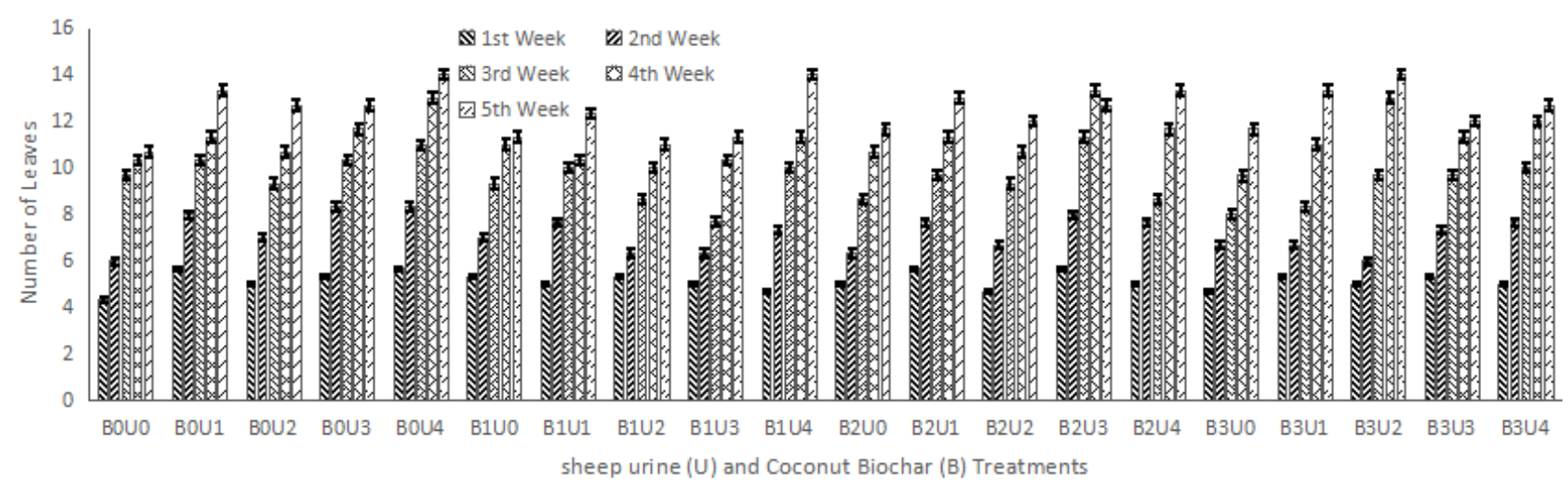

Figure 2. Aplication sheep urine fermentation and biochar coconut in the number of leaves at Coastal sandy soil 


\section{Leaf Length and Width}

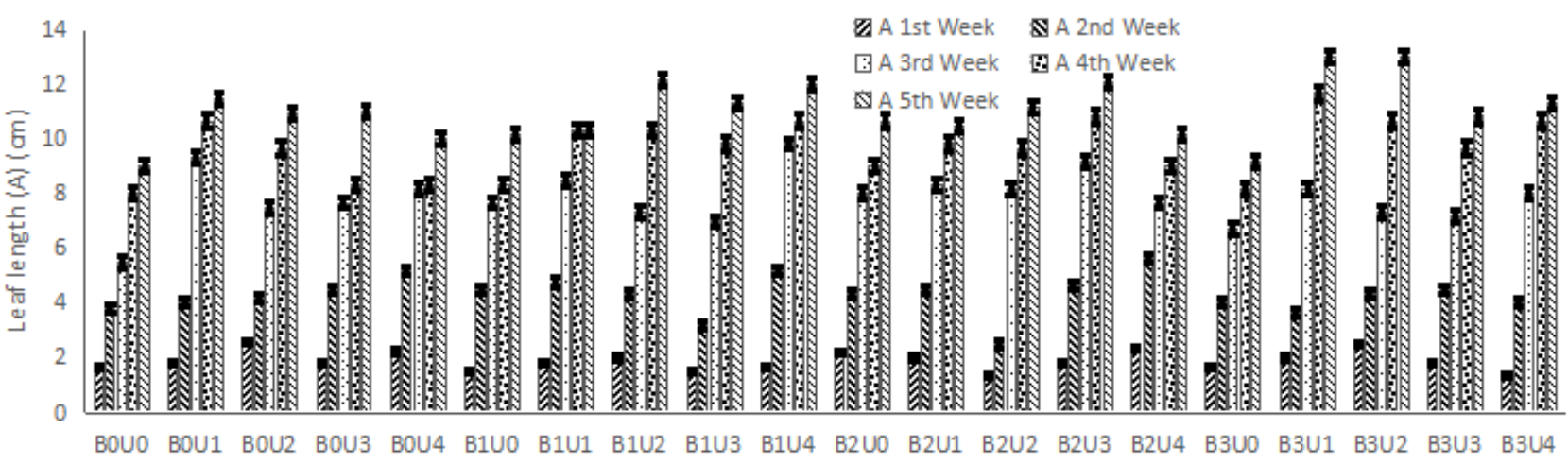

sheep urine (U) and Coconut Biochar (B) Treatments

Figure 3. Aplication sheep urine fermentation and biochar coconut in leaf length with various treatments at Coastal sandy soil

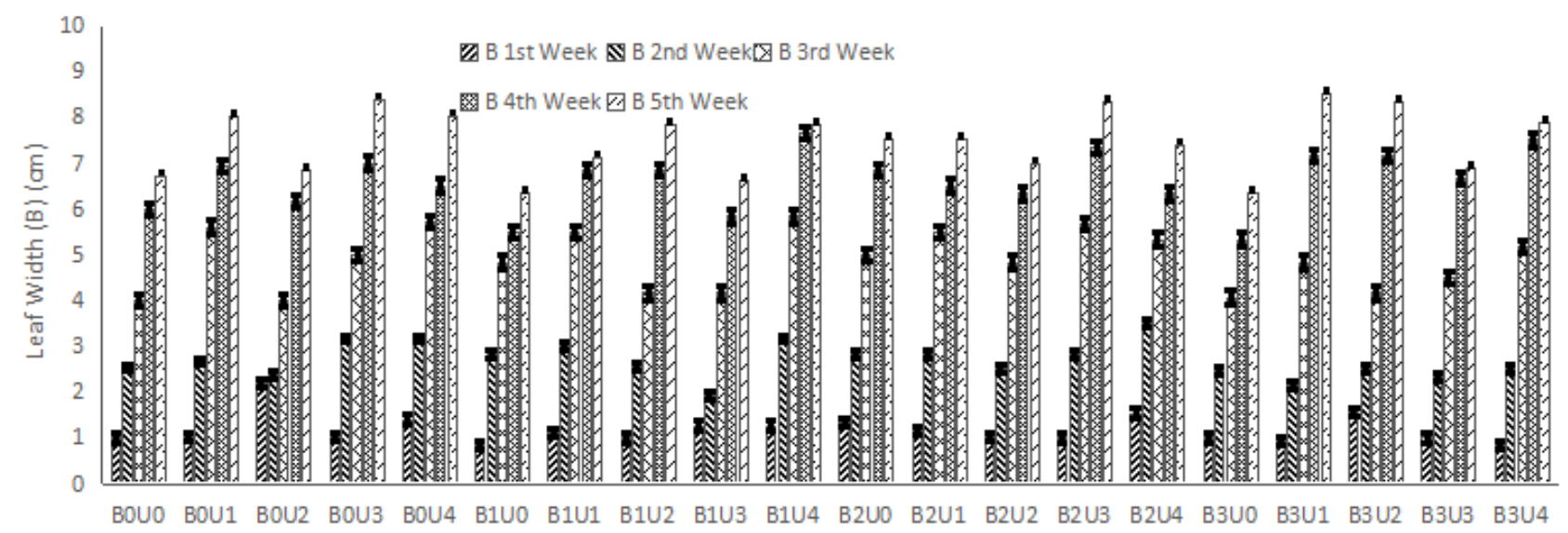

sheep urine (U) and Coconut Biochar (B) Treatments

Figure 4. Aplication sheep urine fermentation and biochar coconut in leaf width at Coastal sandy soil

Pakcoy plants treated with biochar and sheep urine with various concentrations absorb and provide more N, P and K elements from sheep urine, causing the leaves to grow wider and the leaf surface to be wider which is useful for the photosynthesis process which will affect the color of the leaves.

Significant results related to leaf length and width on pakcoy plants occurred in the biochar treatment of 20 tons per hectare and the sheep urine treatment of $50 \mathrm{ml}$ per liter of water and $100 \mathrm{ml}$ per liter of water, for the result is leaf length of $13 \mathrm{~cm}$ and $9 \mathrm{~cm}$ at leaf width compared to that without biochar and sheep urine treatment, i.e. $9 \mathrm{~cm}$ and $7 \mathrm{~cm}$ for the length and width of the leaves. With the increase in the rate of photosynthesis (as the result of increasing of leaf number measure), it will produce carbohydrates in large quantities many. Compound Carbohydrates are the basic ingredients for the synthesis of proteins and other compounds that are used to compose plant organs and plant life activities. 


\section{Leaf Color}

Significant results related to leaf color in pakcoy plants occurred in the biochar treatment of 20 tons per hectare and sheep urine treatment of $100 \mathrm{ml}$ per liter of water, and $150 \mathrm{ml}$ per liter of water, indicating a moderate green color of the leaves compared to plants without treatment produces an olive green color or plants with sheep urine treatment of $200 \mathrm{ml}$ per liter of water produces a strong yellow green leaf color (Table 1).

Table 1. Observation of Leaf Color in aplication sheep urine fermentation and ameliorance of biochar coconut

\begin{tabular}{|c|c|c|c|c|c|}
\hline $\begin{array}{c}\text { Treatme } \\
\mathrm{nt}\end{array}$ & Top Leaf & Upper Leaf & Middle Leaf & Lower Leaf & Bottom Leaf \\
\hline BOU0 & ++ & + & + & + & + \\
\hline B0U1 & ++ & + & + & + & + \\
\hline B0U2 & + & ++ & + & + & + \\
\hline B0U3 & ++ & + & + & + & + \\
\hline B0U4 & ++ & ++ & + & + & + \\
\hline B1U0 & ++ & ++ & + & + & + \\
\hline B1U1 & ++ & + & + & + & + \\
\hline B1U2 & ++ & ++ & + & + & + \\
\hline B1U3 & ++ & + & + & + & + \\
\hline B1U4 & ++ & ++ & + & + & + \\
\hline B2U0 & ++ & ++ & + & + & + \\
\hline B2U1 & ++ & + & + & + & + \\
\hline $\mathrm{B} 2 \mathrm{U} 2$ & +++ & ++ & + & + & + \\
\hline B2U3 & +++ & + & + & + & + \\
\hline B2U4 & +++ & + & + & + & + \\
\hline B3U0 & ++ & + & + & + & + \\
\hline B3U1 & ++ & ++ & + & + & + \\
\hline B3U2 & ++ & ++ & ++ & + & + \\
\hline B3U3 & ++ & ++ & ++ & + & + \\
\hline B3U4 & +++ & ++ & + & + & + \\
\hline
\end{tabular}

Note:

U: Sheep urine fermentation, B: Ameliorane biochar coconut shell, +++: Strong yellow green, ++: Moderate yellow green, +: Olive green

Based on the research that has been done, it can be seen that the application of biochar and treatment of sheep urine on pakcoy plants resulted in the growth of leaf number, length and width of leaves and leaf color on pakcoy plants increased and gave a better effect when compared to no treatment. An increase in the number of leaves will provide more photosynthetic results. Lack of nutrients in the growing media can be added with biochar treatment and sheep urine so that plant growth becomes more optimal. The best achievement of plant growth was produced by the application of biochar 15 tons per hectare and the treatment of sheep urine $150 \mathrm{ml}$ per liter of water. While the application of biochar 20 tons per hectare and treatment of sheep urine $200 \mathrm{ml}$ per liter of water produces a strong green color, this condition is presumably because the concentration of $200 \mathrm{ml}$ per liter of water is too concentrated for pakcoy plant seeds, so that plant growth is disrupted. Fertilization with very high doses can cause poisoning for plants because the salt 
content exceeds the plant's tolerance threshold. Nutrient toxicity can cause damage to plants, plants with excess $\mathrm{N}$ nutrient are characterized by strong yellow green leaf color.

\section{CONCLUSION}

The application of sheep urine liquid waste with mixed media of biochar on pakcoy horticultural plants can be concluded as follows: Treatment of biochar and sheep urine can increase the value for all observed research parameters, i.e. plant height, the number of leaves, length, width, and leaf color in pakcoy horticultural plants. Provision of sheep urine liquid waste with mixed media of biochar with the application of biochar 15 tons per hectare and treatment of sheep urine $100 \mathrm{ml}$ per liter of water gave better growth and yield of pakcoy plants. Biochar and sheep urine liquid waste can be used as alternative organic fertilizers in pakcoy cultivation. For further research need to apply for various horticultural plants and also different planting media.

\section{Acknowledgements}

The authors would like to thank for research institute and community service Universitas Pembangunan Nasional Veteran Yogyakarta which has internal grant cluster research activities for the 2021 fiscal year. We are like to thank at the Faculty of Agriculture to permit and permission to use green house for research.

\section{REFERENCES}

Anomyous (2021). DI Yogyakarta Province in Figures. Special Region of Yogyakarta.

Anomyous (2017). Department of Agriculture Report on the Performance of Government Agencies of DIY Agriculture Service.

Haryanto, E. (2006). Mustard and Lettuce. 9th edn. Jakarta: Penebar Swadaya.

Herlambang S., AZ. P. B. S, H. T. Sutiono, and S. Rina N. (2020a). "Application of coconut biochar and organic materials to improve soil environmental," IOP Conf. Ser.: Earth Environ. Sci., vol. 347, p. 012055, Nov. 2019, doi: 10.1088/1755-1315/347/1/012055.

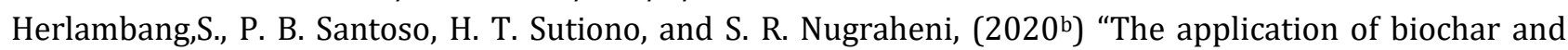
organic matter for proper cultivation on paddy soil," Journal of Degraded and Mining Lands Management, vol. 7, no. 3, Art. no. 3, Apr. 2020, doi: 10.15243/jdmlm.2020.073.2133

Ingold, M. et al. (2015) 'Effects of activated charcoal and quebracho tannin amendments on soil properties in irrigated organic vegetable production under arid subtropical conditions', Biology and Fertility of Soils, 51(3), pp. 367-377. doi: 10.1007/s00374-014-0982-z.

Kurniawan, E., Ginting, Z. and Nurjannah, P. (2017) 'Utilization of goat urine in the manufacture of liquid organic fertilizer on the quality of macro nutrients (NPK)', National Seminar on Science and Technologyi, (23), pp. 1-10. Available at: jurnal.umj.ac.id/index.php/semnastek.

Lehmann, J. and Joseph, S. (2012) 'Biochar for environmental management: An introduction', in Biochar for Environmental Management: Science and Technology, pp. 1-12. doi: https://doi.org/10.4324/9781849770552.

Mariwah, S. and Drangert, J. (2011) 'Community perceptions of human excreta as fertilizer in Peri-Urban agriculture in Ghana', Waste Management \& ResearchResearch, 29, pp. 815-822. doi: https ://doi.org/10.1177/07342 42X10 390073.

Nurida, N. L., Rachman, A. and Sutono S. (2015) 'Potential Soil Improvement Biochar', in. IAARD Press. doi: https://doi.org/10.1017/CB09781107415324.004.

Ria, M. and Asmuliani (2017) 'Pakcoy (Brassica rapa L.) Growth and Yield Test with Liquid Organic Fertilizer Application in a Hydroponic System, Jurnal AGRIFOR, 16(1), pp. 65-74.

Rizki, K., Rasyad, A. and Murniati (2014) 'Effect of Fermented Cow Urine on Growth and Production of Mustard Greens (Brassica rafa)', Jom Fapert, 1(2).

Sutradhar, I., Jackson-deGraffenried, M., Akter, S., McMahon, S. A., Waid, J. L., Schmidt, H.-P., Wendt, A. S., Gabrysch, S. (2021) 'Introducing urine-enriched biochar-based fertilizer for vegetable production: acceptability and results from rural Bangladesh', Environment, Development and Sustainability. 
RSF Conference Series: Engineering and Technology

Vol. 1 (1), 239-243

Application of Sheep Urine Fermentation and Biochar Coconut for Growth Vegetables Plant Susila Herlambang, Danang Yudhiantoro, Indriana Lestari, Muammar Gomareuzzaman 